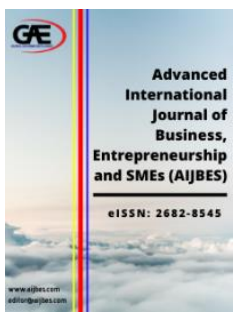

\author{
ADVANCED INTERNATIONAL JOURNAL OF \\ BUSINESS, ENTREPRENEURSHIP AND SMES \\ (AIJBES) \\ www.aijbes.com
}

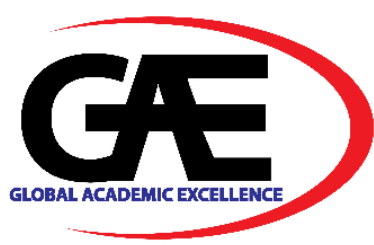

\title{
THE EFFECT OF MARKETING ETHICS AS A MODERATOR ON THE RELATIONSHIP BETWEEN CUSTOMER ORIENTATION AND SMES PERFORMANCE IN SAUDI ARABIA
}

\author{
Moad Hamod M Saleh ${ }^{1 *}$, Adi Anuar Azmin², Ummi Naiemah Saraih ${ }^{3}$ \\ 1 Faculty of Applied and Human Sciences, Universiti Malaysia Perlis, Malaysia \\ Email: moad.hamod2000@ hotmail.com \\ 2 Faculty of Applied and Human Sciences, Universiti Malaysia Perlis, Malaysia \\ Email: adianuar@unimap.edu.my \\ 3 Faculty of Applied and Human Sciences, Universiti Malaysia Perlis, Malaysia \\ Email: ummi@unimap.edu.my \\ * Corresponding Author
}

\section{Article Info:}

\section{Article history:}

Received date: 01.05.2021

Revised date: 11.05.2021

Accepted date: 11.06 .2021

Published date: 30.06 .2021

To cite this document:

Saleh, M. H. M., Azmin, A. A., \& Saraih, U. N. (2021). The Effect Of Marketing Ethics As A Moderator On The Relationship Between Customer Orientation And SMEs Performance In Saudi Arabia. Advanced International Journal of Business, Entrepreneurship and SMEs, 3 (8), 119-138.

DOI: $10.35631 /$ AIJBES.38008.

This work is licensed under $\underline{\mathrm{CC} B Y} 4.0$

\section{(1) (1)}

\section{Abstract:}

Recent literature has demonstrated the importance of consumer orientation (CO) for small and medium-sized enterprises (SMEs); however, doubts persist about how $\mathrm{CO}$ can improve SMEs performance due to its ambiguity. We examine the marketing ethics (ME) that govern the relationship between COs and SMEs. A proposed model was empirically tested using a structural equation model (SEM) on 408 manufacturing SMEs in Saudi Arabia. The findings indicate that $\mathrm{CO}$ has a positive effect on the performance of SMEs and, more importantly, that this effect is indirect because ME fully moderates it. These findings indicate that $\mathrm{CO}$ improves performance when firms invest in marketing ethics development. While consumer orientation is critical, it may not be enough to boost performance if the firm is unable to adhere to marketing ethics practices.

Keywords:

Customer Orientation, Marketing Ethics, SMEs Performance, KSA 
Volume 3 Issue 8 (June 2021) PP. 119-138 DOI 10.35631/AIJBES.38008

\section{Introduction}

According to the entrepreneurship literature, SMEs are having great influences on the countries' economies because of their great number and proportion of workforce participation in them. SMEs constitute, particularly in the developing countries, the huge majority of firms and generate most jobs. They are the driving force behind economic development and have a huge effect on these countries' economies (Ahmad, 2012; Al-Hakimi \& Borade, 2020; Cicea et al., 2019). In the Arab countries, especially the Gulf countries, SMEs are the foundation of the private industry, accounting for $90 \%$ of all commercial operations (Genc et al., 2019), 80\% of total employment, and 60\% of GDP (PWC report, 2019). As a result, strengthening the competitiveness of SMEs in developing economies is critical for those countries' economic development.

The firms surveyed are small and medium-sized enterprises (SMEs) in KSA, one of the region's most active economies. Between 2011 and 2019, the Saudi national economy's average GDP growth rate was 3.3 percent. According to the Jeddah Chamber of Commerce and Industry (2018), small and medium-sized enterprises (SMEs) account for approximately $90 \%$ of all firms and $25 \%$ of total employment. Though, SMEs engage only $30 \%$ to the national GDP, a low percentage when compared to both developing and developed economies, as SMEs contribute $60 \%, 30 \%, 55 \%$, and $63 \%$ of GDP in the UAE, Bahrain, Turkey, and Spain, respectively (Hilman et al., 2019; Vision 2030 report,2018). This low performance of SMEs in the KSA reflects a critical issue and provides an opportunity for researchers to examine the primary factors underlying this status.

SMEs face significant pressure from the current business environment's competitive environment, requiring the acceptance of critical strategic options for sustainability. Consumer orientation (CO) is one such strategic option, particularly for SMEs, given the close relationship between managers/owners of SMEs and their clients (Brockman, et al., 2012). CO was defined by Narver and Slater (1990) as "the sufficient understanding of one's target buyers to be able to create superior value for them continuously" (p: 21), which is a term that is frequently used in marketing literature (Neneh, 2018; Wang et al., 2016; Alteren \& Tudoran, 2016). CO was already defined as a critical factor in determining a firm's performance (Neneh, 2018; Smirnova, et al., 2018; Kirca, et al., 2005) and as the primary focus of a firm's relationship with its market (Neneh, 2018; Pekovic, \& Rolland, 2016). However, researchers are increasingly skeptical of CO's universally beneficial effect on firm performance in a variety of contexts. (e.g., Kirca, et al., 2005; Smirnova, et al., 2018; Pekovic \& Rolland, 2016), owing to the lack of conclusive results from previous studies. Whereas some researchers failed to replicate the positive relationship between $\mathrm{CO}$ and organazation performance under certain circumstances (Neneh, 2018, 2016; Feng et al., 2019; Brockman et al., 2012; Zhou et al., 2007;), others discovered an inverse relationship between them (; Feng et al., 2019; Brockman et al., 2018; Neneh, 2018; Chin et al., 2013; Sorensen, 2011; Solberg \& Olsson, 2010; Zhou et al., 2007). Thus, these inconclusive findings have prompted some researchers to recommend additional research to gain a more complete understanding of the nature of the relationship between CO and firm performance in a variety of contexts (Kadic-Maglajlic et al., 2017; Brockman et al., 2012), as well as to address the question of when and how CO improves performance, with a particular emphasis on contingency factors. Even so, the majority of researchers concentrated on external factors that may have an effect on the CO-performance relationship, ignoring the moderating influence of internal factors. As a result, this study focuses on marketing ethics (ME) as an internal factor that influences customer-oriented businesses' behaviours. 


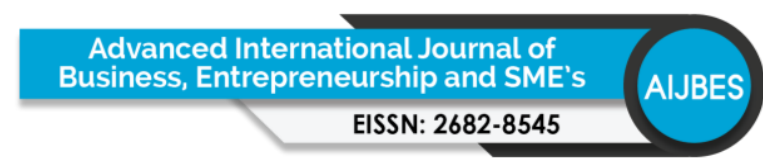

Volume 3 Issue 8 (June 2021) PP. 119-138 DOI 10.35631/AIJBES.38008

While CO is critical for businesses, it is also believed that ethical behaviour enhances a firm's long-term performance (Abratt et al., 1992). ME is frequently viewed as a subset of a business ethic (Murphy, 2002) concerned with the ethical principles applicable to the marketing function (Majtán \& Dubcová, 2008). We argue, using recourse-based theory and congruence theory, that ME serves as a critical reference for managers and firms when making decisions and allocating resources for various activities (Williams \& Murphy, 1990). Thus, ME may be critical role in meeting customers' ethical needs, thereby affecting the relationship between $\mathrm{CO}$ and business performance. In the same way, when ME is elevated, $\mathrm{CO}$ is more likely to improve firm performance.

Until now, little experimental attention was given to $\mathrm{ME}$ concurrently with $\mathrm{CO}$ and its performance consequences. This gap is addressed by investigating the moderating effect of $\mathrm{ME}$ on the relationship between $\mathrm{CO}$ and performance. The research makes two contributions. To begin, the researchers demonstrate that $\mathrm{ME}$ acts as a moderator in the CO-firm performance relationship. This study expands the previously identified set of contingency factors affecting the CO-performance relationship by identifying $\mathrm{ME}$ as a vital and determining factor. Second, and perhaps most significantly, only a few previous studies in the KSA have attempted to evaluate market orientation and its impact on various sectors, including the manufacturing sector (Aldakhil et al., 2020; Ali et al.,2020; Bhuian \& Habib, 2005; Bhuian, 1998) and the service sector, such as banks (Bhuian, 1997). To the best of the researchers' knowledge, there is no empirical research that examines the relationship between market orientation as a multidimensional construct or CO as one of its dimensions and SMEs performance in Saudi Arabia. Thus, this research seeks to Bridge the gap by focusing on SMEs in the KSA and providing empirical evidence on the subject.

\section{Literature Review}

\section{Customer Orientation (CO)}

Over the last years, $\mathrm{CO}$ has become one of the most studied concepts given to its important influence on business performance. $\mathrm{CO}$ is seen as an organizational culture, which considers the current and prospective customers' needs and desires, and continuously contributes to creating value (Narver \& Slater, 1990). In this sense, customer-oriented firms take advantage of information related to the present and future customers' requirements and desires to deliver high value-added offers (Hilman \& Kaliappen, 2014). As such, CO allows the firm to participate information on its customers with all employees, enabling constantly having opportunities to serve the customers well (Grawe et al., 2009; Hilman \& Kaliappen, 2014). In regards to this, $\mathrm{CO}$ requires firms to understand their customers' value chain to consistently create higher value for them (Narvar \& Slater, 1990), thus enhancing the performance of those firms. By focusing on creating value for customers, a firm can enhance customer satisfaction and loyalty as well as innovation and successful performance (Frambach et al., 2016).

\section{SME Performance}

Firm performance is a critical metric of all types of organizations or industries in the world, which include SMEs, due to it is concerning with sustainability (Yustian, 2021). Performance is a very broad term that can be measured in many ways according to the target purpose. SMEs' performance was measured from a quantitative perspective depending on indicators: financial, customers' number, production's level (Anggadwita, \& Mustafid, (2014).), profitability, market share, productivity, costs and liquidity (Gupta, \& Batra, (2016)), etc. as well as a qualitative perspective depending on indicators: goals accomplishment, employee behaviour, leadership Copyright (C) GLOBAL ACADEMIC EXCELLENCE (M) SDN BHD - All rights reserved 


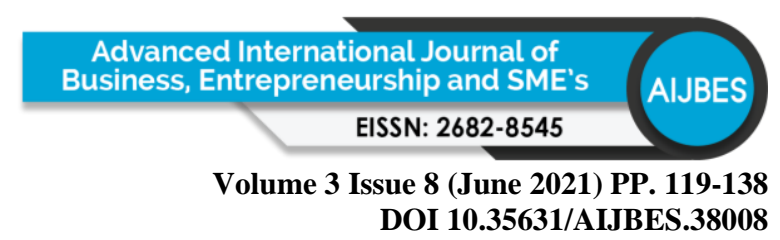

pattern (Anggadwita \& Mustafid, 2014), innovation (Sheehan, 2013), customer satisfaction (Alpkan et al., 2007), etc. While Gopang et al. (2017), used14 pointers to evaluate SMEs performance: productivity, employee satisfaction, working capital, sales, profits, immediate delivery, effectiveness in production operations, reputation, product quality, goals fulfilment, client's number, ease of supervision, low production costs and diversification.

\section{Marketing Ethics (ME)}

Drawing on the literature on marketing and management, $\mathrm{ME}$ is generally defined as a part of a business ethic that handles the ethical values underlying marketing function and regulation (Majtán \& Dubcová, 2008). The possibility of applying ethics, therefore, to every component of the marketing mix, i.e. product, promotion, price, and distribution (Alshurideh, et al.,2016; Takala, T., \& Uusitalo, O. 1996). With the changes in marketing practice, ME is changing. For example, with the outbreak of the Corona pandemic in 2020, major changes have occurred in how marketing is implemented and constantly changing business models evolve, where some business' sectors were completely closed for several months as "non-essential services", prompting a contemplation of how the business could change going forward in the future (Ferrell, \& Ferrell, 2021; Hopkins, et al., 2021). From an ethical perspective, consumers and other participants critically re-evaluate and question what is acceptable behavior (He \& Harris, 2020).

\section{Hypotheses Development}

\section{CO and SME Performance}

Examining the relationship of $\mathrm{CO}$ to SME performance represented an extensive research matter in the current business environment (Hilman \& Kaliappen, 2014). Customer-oriented firms usually engage in behaviors that enhance their performance through the long-term satisfaction of their customers. Saxe and Weitz (1982) argue the importance of adopting a customer-oriented approach when firms strive to meet the requirements of their customers. Numerous prior studies created a strong significant relation among $\mathrm{CO}$ and performance (Asikhia, 2010; Gaur et al., 2011; Neneh, 2016,2018; Pongwiritthon \& Awirothananon, 2014). For example, Sorensen (2009) discovered that CO has a significant positive effect on the performance of Danish manufacturing firms. Prior to that, AppiahAdu \& Singh (1998) discovered a positive effect of CO on SME performance using a UK sample of SMEs. Recently, Bamfo \& Karaa (2019) concluded in their study that CO has a positive effect on the performance of SMEs in Ghana. Furthermore, Abdulrab et al. (2020) and Ali et al. (2020) discovered a positive and significant relationship between $\mathrm{CO}$ and performance in the context of SMEs in the Kingdom of Saudi Arabia. Given the above, we propose that:

H1. CO positively associated with SME performance.

\section{The Moderating of Marketing Ethics}

It is believed that ethical behavior enhances a firm's long-term performance (Abratt et al., 1992). Additionally, Williams, O. F., \& Murphy, P. E. (1990) highlighted the significance of guidelines and norms that guiding administrators and businesses in making important decisions and resource allocation. Indeed, ethical issues frequently arise in new marketing practices as a result of the firm's focus on financial concerns and disregard for ethical concerns (Ferrell, O. C., \& Ferrell, L. 2021; Majtán \& Dubcová, 2008). As a consequence, firms must establish an ethical standard for their product-marketing activities in order to practice and implement the highest standards of marketing ethics within their organizations. Relating to that, Hopkins, et al., (2021) and Takala \& Uusitalo (1996) proved the significance of ethical communication in Copyright $@$ GLOBAL ACADEMIC EXCELLENCE (M) SDN BHD - All rights reserved 
Volume 3 Issue 8 (June 2021) PP. 119-138 DOI 10.35631/AIJBES.38008

developing and reorganizing relationships among businesses and customers. Likewise, Ferrell, O. C., \& Ferrell, L. (2021 asserts that marketing ethics is an organizational responsibility that is critical for developing and maintaining long-term advantageous relationships with customers.

Prior studies shed the light on the correlation and positive relationship between $\mathrm{CO}$ and firm performance (Grissemann et al., 2013; Hassen \& Singh, 2020; Howe et al., 1994; Thoumrungroje \& Racela, 2013), with some even exhibiting the relationship between ethical behavior and CO (Howe et al., 1994), and firm performance (Abratt et al., 1992).To remain competitive in the market, the firm must consider ethical issues when conducting its various activities (Long \& Driscoll, 2008) and continuously improve its CO practices (AppiahAdu \& Singh, 1998). Moreover, a firm that practices high ME would enhance performance (Hosmer, 1994), as well as enhance its corporate image and reputation (Roberts \& Dowling, 2002), as the ethical behavior positively relate to trust and satisfaction, thus enhancing relationship quality between firm and customers (Orlitzky et al., 2003; Waddock \& Graves, 1997; Lagace et al., 1991). Marketing researchers also in the past (e.g., Luo \& Bhattacharya, 2006) indicated that $\mathrm{ME}$ is significantly related to $\mathrm{CO}$ and affects performance. Ethical marketing practices provide the system through which the relationships based on trust between firms and their customers are rigorous (Howe et al., 1994; Oakes, 1990). The managers' efforts to reduce the ethical problems that firms can face to increase happier customers and increase sales and profits may lead (Dubinsky \& Ingrain, 1984). However, no previous studies are known to have addressed ME as a moderator in the CO-firm performance relationship. Thus, the following hypothesis is proposed:

$\mathrm{H} 2$. The relationship between CO and SME performance is moderated by ME.

Depending on the theoretical framework and the hypotheses derived previously, the conceptual model can be presented as in Fig. 1.

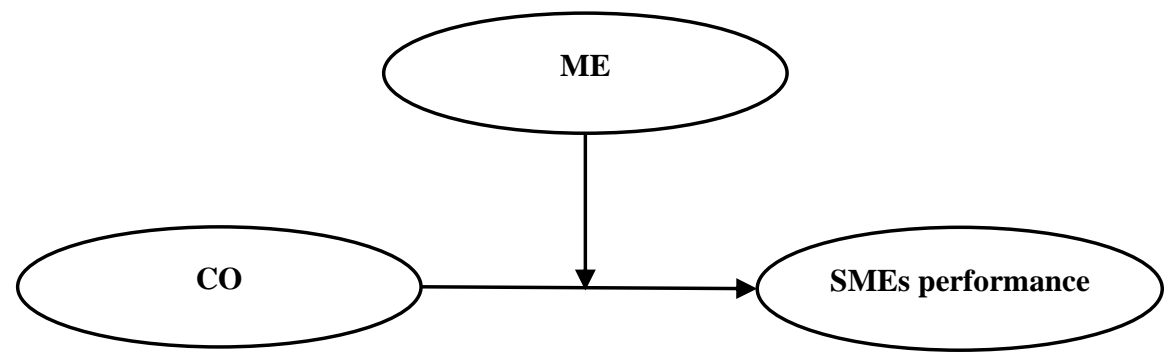

Figure. 1. Conceptual model

\section{Methodology}

\section{Study Sample and Data Collection}

A quantitative approach is use in this study because it seeks to examine the moderation effect of $\mathrm{ME}$ in the CO-SME performance relationship. Where it relied on primary data collected from manufacturing' SMEs in Riyadh, Makkah, and the West region, which involve the highest proportion of SMEs in the country for the various sectors. Manufacturing firms frequently seek to achieve high performance in order to cope with market disruptions caused by the Corona pandemic, so the manufacturing sector was studied. This study's target population includes Copyright (C) GLOBAL ACADEMIC EXCELLENCE (M) SDN BHD - All rights reserved 
Volume 3 Issue 8 (June 2021) PP. 119-138 DOI 10.35631/AIJBES.38008

many manufacturing industries, such as food and beverage, packaging, furniture, textiles, plastic, and chemical and petrochemical. According to the database from the Jeddah Chamber of Commerce and Industry (2018), there are 5820 manufacturing SMEs in KSA. SMEs are defined, according to the Saudi Ministry of Commerce and Industry (2018), as "a business that employs a maximum of 200 employees and has an annual sales turnover of less than 13.3 million USO".

The simple random sampling method was employed to select respondents, which is known for its accuracy, impartiality, and ability to produce generalizable results. A sample size of 361 SMEs was determined as a minimum from the entire study population, as recommended by Krejcie \& Morgan (1970) for appropriate sample size estimation. Then, to solve the nonresponse problem and to reduce the sample size error, the sample size was doubled to 722 (Hair et al., 2011). Out of 722 questionnaires, 471 were filled out and returned, leaving 408 usable questionnaires with a response rate of $56.5 \%$ after excluding 22 invalid questionnaires. Table 1 displays the demographics of the respondents.

Table 1: The Demographics of The Respondents.

\begin{tabular}{|c|c|c|}
\hline Category & Frequency & Percentage \\
\hline \multicolumn{3}{|l|}{ Position: } \\
\hline Owner & 78 & 19.1 \\
\hline Manager & 330 & 80.9 \\
\hline \multicolumn{3}{|l|}{ Gender: } \\
\hline Male & 376 & 92.2 \\
\hline Female & 32 & 7.8 \\
\hline \multicolumn{3}{|l|}{ Education: } \\
\hline High School & 83 & 20.3 \\
\hline Bachelor & 177 & 43.4 \\
\hline Master & 137 & 33.5 \\
\hline Doctoral & 11 & 2.8 \\
\hline \multicolumn{3}{|l|}{ Existence: } \\
\hline $\begin{array}{l}\text { Less than } 5 \\
\text { years }\end{array}$ & 105 & 25.7 \\
\hline 5- 10 years & 117 & 28.7 \\
\hline 11-15 years & 95 & 23.3 \\
\hline $\begin{array}{ll} & \text { More than } 15 \\
\text { years } & \\
\end{array}$ & 91 & 22.3 \\
\hline
\end{tabular}

\section{Measures}

We used a questionnaire tool and a five-point Likert scale $(5=$ Strongly Agree to $1=$ Strongly Disagree) to assess the responses in order to collect the necessary data for measuring the relationships in the proposed model. All of the questionnaire measures were developed using the literature. Where CO was measured using six items adopted and adapted from O'Dwyer \& Gilmore (2019), Smirnova et al., (2011), and Narver \& Slater (1990). While SME performance was measured in general by six items adopted and adapted from Ali et al., (2020); and Saha et al., (2020). As for ME, it was assessed using a 25-item scale adapted and adopted from AlNashmi \& Almamary (2017), Cheung \& To (2020), Vitell et al., (1993a,b), and Yoo \& Donthu (2002). 


\section{Ethical considerations}

The study was performed based on the opinions of owners and managers of SMEs in KSA, according to their willingness to participate (voluntary) with anonymity and to ensure that all information was kept. As a study in social science, it is devoid of any human experiment and doesn't need ethical approval. S, the intuition didn't require any ethical approval.

\section{Results}

Smart PLS 3. was used to analyze the data, as suggested by Ringle et al (2005). PLS-SEM possesses a number of characteristics that contribute to its widespread use in management research (Goaill et al., 2014). It is considered a suitable method for small samples (Henseler et al., 2009), as it demonstrates greater statistical power than the covariance-based SEM when applied to complicated models with small sample sizes (Reinartz et al., 2009). This is particularly pertinent in the current analysis, which included 171 cases.

This study evaluates the proposed PLS model in two stages (Valerie, 2012). To begin, a reliability test was conducted to ascertain the scale items' internal consistency, followed by a confirmatory factor analysis to ascertain construct validity, including convergent and discriminant validity (CFA). Cronbach's alpha $(\alpha)$ and consistency reliability (CR) must both be greater than 0.70 (Hair et al., 2011); convergent validity is achieved when all items are statistically significant, with loadings of 0.70 or greater (Hair et al., 2011). (Hair et al., 2011). Additionally, the average variance extracted (AVE) must be greater than or equal to 0.50, a widely accepted cut-off value (Hair et al.,2011). Second, the structural model was analyzed to determine its R2, effect size, and predictive relevance; additionally, the research hypothesis was validated using bootstrapping. As displayed in Table 1, the factor loadings between constructs and indicators were greater than 0.60 (ranged from 0.611 to 0.925 ), indicating individual reliability.

Table 1: Loadings and Cross Loadings

\begin{tabular}{clccc}
\hline Construct & Items & CO & ME & $\begin{array}{c}\text { SME } \\
\text { performance }\end{array}$ \\
\hline \multirow{6}{*}{ CO } & CO1 & $\mathbf{0 . 6 1 1}$ & 0.436 & 0.393 \\
& CO2 & $\mathbf{0 . 7 9 9}$ & 0.483 & 0.454 \\
& CO4 & $\mathbf{0 . 8 1 8}$ & 0.488 & 0.424 \\
& CO5 & $\mathbf{0 . 7 8 4}$ & 0.588 & 0.513 \\
& CO6 & $\mathbf{0 . 8 5 8}$ & 0.691 & 0.530 \\
CO7 & $\mathbf{0 . 8 2 8}$ & 0.714 & 0.498 \\
\hline ME1 & 0.506 & $\mathbf{0 . 6 7 4}$ & 0.420 \\
ME2 & 0.567 & $\mathbf{0 . 7 7 6}$ & 0.496 \\
ME & 0.675 & $\mathbf{0 . 8 0 8}$ & 0.536 \\
& ME3 & 0.684 & $\mathbf{0 . 8 2 3}$ & 0.568 \\
& ME4 & 0.660 & $\mathbf{0 . 8 5 5}$ & 0.650 \\
ME5 & 0.580 & $\mathbf{0 . 7 9 1}$ & 0.598 \\
ME6 & 0.541 & $\mathbf{0 . 8 6 4}$ & 0.569 \\
ME7 & 0.626 & $\mathbf{0 . 8 9 3}$ & 0.588 \\
ME8 & 0.596 & $\mathbf{0 . 8 7 1}$ & 0.589 \\
ME9 & 0.590 & $\mathbf{0 . 8 4 4}$ & 0.518 \\
ME10 & 0.521 & $\mathbf{0 . 8 5 3}$ & 0.512 \\
ME11 & 0.654 & $\mathbf{0 . 8 6 9}$ & 0.556
\end{tabular}


Volume 3 Issue 8 (June 2021) PP. 119-138 DOI 10.35631/AIJBES.38008

\begin{tabular}{clccc}
\hline Construct & Items & CO & ME & $\begin{array}{c}\text { SME } \\
\text { performance }\end{array}$ \\
\hline \multirow{6}{*}{ ME13 } & 0.644 & $\mathbf{0 . 8 9 5}$ & 0.557 \\
& ME14 & 0.669 & $\mathbf{0 . 9 1 9}$ & 0.586 \\
& ME15 & 0.640 & $\mathbf{0 . 9 0 8}$ & 0.544 \\
& ME16 & 0.636 & $\mathbf{0 . 9 0 3}$ & 0.513 \\
& ME17 & 0.657 & $\mathbf{0 . 8 8 2}$ & 0.560 \\
& ME18 & 0.664 & $\mathbf{0 . 8 8 0}$ & 0.491 \\
& ME19 & 0.697 & $\mathbf{0 . 8 7 9}$ & 0.544 \\
SME & ME20 & 0.632 & $\mathbf{0 . 8 4 6}$ & 0.522 \\
\hline \multirow{6}{*}{ ce } & SME1 & 0.583 & 0.593 & $\mathbf{0 . 8 9 2}$ \\
& SME2 & 0.533 & 0.520 & $\mathbf{0 . 8 9 4}$ \\
& SME3 & 0.425 & 0.461 & $\mathbf{0 . 8 1 3}$ \\
& SME4 & 0.508 & 0.571 & $\mathbf{0 . 9 0 7}$ \\
& SME6 & 0.552 & 0.567 & $\mathbf{0 . 9 0 8}$ \\
& SME7 & 0.553 & 0.588 & $\mathbf{0 . 9 0 5}$ \\
& SME8 & 0.538 & 0.655 & $\mathbf{0 . 8 8 7}$ \\
& SME9 & 0.567 & 0.638 & $\mathbf{0 . 9 2 2}$ \\
& SME10 & 0.572 & 0.592 & $\mathbf{0 . 9 2 5}$ \\
\hline
\end{tabular}

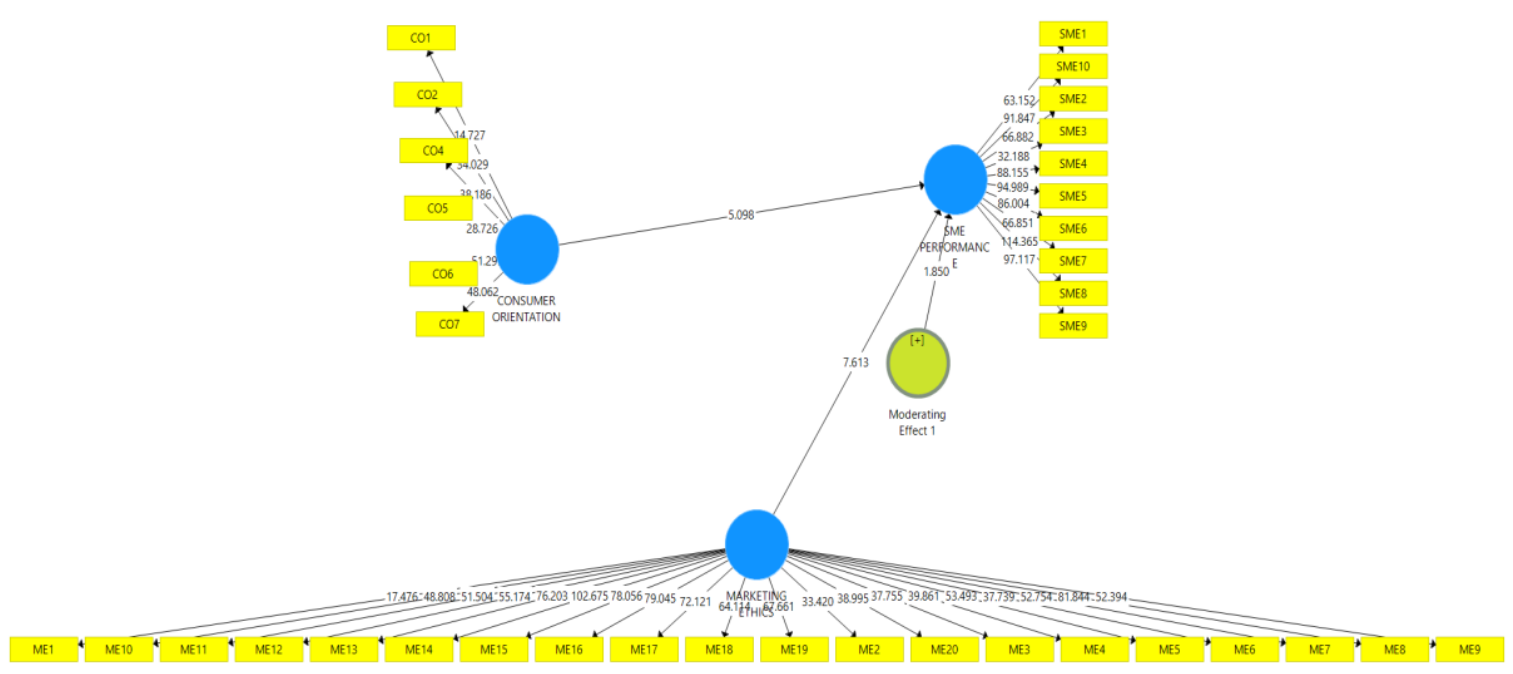

Figure 2: Measurement Model

Furthermore, the results in Table 2 obtained from the Convergent validity analysis showed good convergent validity, where all the CRs values ranged between 0.906 and 0.982 , and Cronbach's alpha values reached from 0.874 to 0.980. As well as, AVEs ranged between 0.619 and 0.806 , which were all within the suggested limits. 
Table 2: Convergent Validity Analysis

\begin{tabular}{lccc}
\hline \multicolumn{1}{c}{ Construct } & $\boldsymbol{\alpha}$ & $\mathbf{C R}$ & AVE \\
\hline CO & 0.874 & 0.906 & 0.619 \\
ME & 0.980 & 0.982 & 0.728 \\
SME & 0.973 & 0.977 & 0.806 \\
performance & & $\alpha=$ Cronbach's Alpha \\
\hline $\begin{array}{l}\text { Note: CR = Composite Reliability, } \\
\text { AVE }=\text { Average Variance Extracted }\end{array}$ & \multicolumn{2}{c}{} \\
\hline
\end{tabular}

To examine the discrimination of the latent factors, the discriminant validity was done. As shown in Table 3, the discriminate validity of the measurement model is high, since the values of $\sqrt{A V E}$ outweigh the correspondent correlations of all factors (Fornell \& Larcker, 1981). This means that the correlation of the indicators with their factors is greater than other factors.

Table 3: Discriminant Validity Analysis

\begin{tabular}{lccc}
\hline Construct & CO & ME & $\begin{array}{c}\text { SME } \\
\text { performan } \\
\text { ce }\end{array}$ \\
\hline CO & $\mathbf{0 . 7 8 7}$ & & \\
ME & 0.730 & $\mathbf{0 . 8 5 3}$ & \\
SME performance & 0.600 & 0.644 & $\mathbf{0 . 8 9 8}$ \\
\hline
\end{tabular}

In order to validate the study hypotheses and figure out if the proposed model is appropriate, the coefficient of determination (R2) was computed overall, which shows three degrees of predictability, as per Chin (1998) $(0.10=$ weak; $0.33=$ moderate; $0.67=$ substantial $)$. The outcome denotes that EO and AC can account for $57.3 \%$ of the variance in the SCR, which falls within the moderate range.

Additionally, effect size has calculated for the latent variables upon the dependent variable using f2 analysis that complements $\mathrm{R}^{2}$ (Chin, 2010). Since f2 is not available in PLS automatically, it is calculated manually as per the formula shown in Table 4. According to Cohen (2013), the f2 values of $(0.35,0.15$, and 0.02$)$ respectively are used to illustrate the effect sizes (large, medium, and small) for the predictive variables. Hence the showing a small effect size of CO (0.071), and a medium effect size of ME (0.169) on SME performance, while no effect of $\mathrm{CO} * \mathrm{ME}$.

Table 4: Effect Sizes of The Latent Variables

\begin{tabular}{lccc}
\hline Construct & $\mathbf{R}^{2}$ & $\boldsymbol{f}^{\mathbf{2}}$ & $\begin{array}{c}\text { Effect size } \\
\text { rating }\end{array}$ \\
\hline SME performance & 0.454 & & \\
CO & - & 0.071 & Small effect \\
ME & - & 0.169 & Medium effect \\
CO* ME & - & 0.005 & No effect \\
\hline
\end{tabular}


Volume 3 Issue 8 (June 2021) PP. 119-138

DOI 10.35631/AIJBES.38008

Besides, the model's predictive power was tested, as the model has predictive quality when the value of crossed-redundancy $\left(\mathrm{Q}^{2}\right)$ above zero as suggested by Hair et al. (2011). $\mathrm{Q}^{2}$ is calculated by the formula shown in Table 5, where the outcomes display that the $\mathrm{Q}^{2}$ value of SME performance is 0.359 , confirming that the model has an appropriate prediction quality.

Table 4: Effect Sizes of The Latent Variables

\begin{tabular}{lccc}
\hline Construct & $\mathbf{R}^{\mathbf{2}}$ & $\boldsymbol{f}^{\mathbf{2}}$ & $\begin{array}{c}\text { Effect size } \\
\text { rating }\end{array}$ \\
\hline SME performance & 0.454 & & \\
CO & - & 0.071 & Small effect \\
ME & - & 0.169 & Medium effect \\
CO* ME & - & 0.005 & No effect \\
\hline
\end{tabular}

Besides, the model's predictive power was tested, as the model has predictive quality when the value of crossed-redundancy $\left(\mathrm{Q}^{2}\right)$ above zero as suggested by Hair et al. (2011). $\mathrm{Q}^{2}$ is calculated by the formula shown in Table 5, where the outcomes display that the $\mathrm{Q}^{2}$ value of SME performance is 0.359 , confirming that the model has an appropriate prediction quality.

Table 5: Predictive Quality of The Model

\begin{tabular}{cccc}
\hline Total & SSO & SSE & $\mathbf{Q}^{2}$ \\
\hline SME performance & 4080.000000 & 2614.185 & 0.359 \\
\hline$Q^{2}=1-S S E / S S O$ & & & \\
\hline
\end{tabular}

Finally, the hypothesized relationships of the model were tested as shown in Figure 3 and Table 6.

Table 6: Hypotheses Testing

\begin{tabular}{ccccccc}
\hline H & Relationship & $\begin{array}{c}\text { Path } \\
\text { coefficie } \\
\text { nt }\end{array}$ & $\begin{array}{c}\text { Standar } \\
\text { d error }\end{array}$ & $\begin{array}{c}\text { T- } \\
\text { value }\end{array}$ & $\begin{array}{c}\text { P- } \\
\text { value }\end{array}$ & Result \\
\hline $\begin{array}{c}\mathrm{H} \\
1\end{array}$ & $\mathrm{CO} \rightarrow$ SME performance & 0.297 & 0.058 & 5.098 & 0.000 & Yes \\
$\mathrm{H}$ & $\mathrm{CO} * \mathrm{ME} \rightarrow$ SME performance & 0.049 & 0.026 & 1.850 & 0.065 & No \\
\hline \multicolumn{6}{c}{$\begin{array}{l}\text { Notes: } \text { t-values }>1.96^{*}(p<0.05) ; \\
\text { Bootstrapping based on } n=600 \text { subsamples }\end{array}$} \\
\hline
\end{tabular}




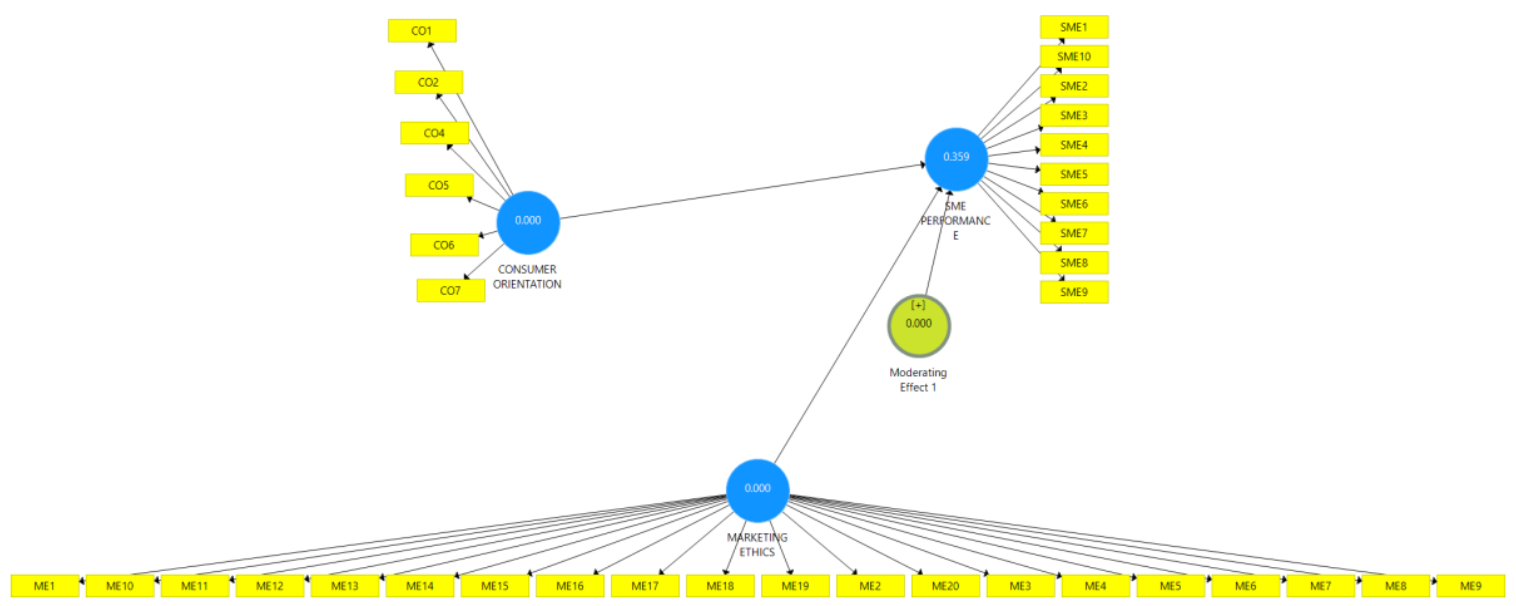

Figure 3: Structural Model

\section{Discussion and Implications}

The purpose of this study is to investigate the relationship between $\mathrm{CO}$ and SME performance in a developing economy like the KSA. CO was hypothesized to boost SMEs' performance. The empirical evidence supports $\mathrm{H} 1$, indicating a positive correlation between $\mathrm{CO}$ and SME performance, which is consistent with previous research (Brockman et al., 2012; Feng et al., 2019; Maurya et al., 2015; Neneh, 2018). This is in contrast to Chin et al. (2013) and Smirnova et al. (2011), who concluded that no correlation exists between customer orientation and organizational outcomes. In terms of KSA, it appears as though CO is an effective tool for SMEs to improve their performance, which can be attributed to the locally prevalent or recognized consumer-to-business relationship (Ali, et al.,2020). This finding demonstrates that when SMEs adopt CO, they are able to better meet the needs and expectations of their customers through the development of innovative products and services, as opposed to SMEs that do not adopt CO (Ali, et al., 2020). As a result, consumer-oriented SMEs achieve superior performance. This finding adds weight to the prior research's argument about the critical role of CO in enhancing SMEs' performance, particularly in terms of creating superior customer value while also considering the interests of other key stakeholders. Through an interest in customer information, consumer-oriented firms are more likely to respond to changing consumer needs through the development of innovative products (Masa'deh et al., 2018). Even so, this research not only replicates the significant correlation between $\mathrm{CO}$ and performance, but also provides insight into the performance implications of CO in the Saudi Arabian environment. This is extremely important from this angle, as prior researches in Saudi Arabia have mostly addressed market orientation, not customer orientation (Ali, et al.,2020; Frambach, et al., 2016; Brockman, et al., 2012).

Additionally, this study examines the moderating effects of $\mathrm{ME}$ and the synergistic effect of ethical marketing practices on the CO-performance relationship of SMEs. Contrary to expectations, the empirical findings indicated that ME had no moderating effect on the relationship between $\mathrm{CO}$ and SMEs. That is, the interaction between $\mathrm{CO}$ and $\mathrm{ME}$ is negligible in the Saudi context. This finding is in contrast to Ferrell, O., and Ferrell, L. (2021) and Howe et al. (1994), that discovered a positive and statistically significant correlation between ethical and customer-oriented behavior. This finding implies that small and medium-sized businesses in the Kingdom of Saudi Arabia must consider ethical practices, including marketing ethics, and the importance of implementing them throughout the marketing process, from product 
development to pricing, promotion, and distribution, in order to retain existing customers and attract new ones.

\section{Theoretical Implications}

Theoretically, this study's primary contribution is the unification of $\mathrm{CO}$ and ME into a single framework. The majority of previous research on $\mathrm{CO}$ and $\mathrm{ME}$ was conducted independently, leaving us with an incomplete understanding of these conditions. Although extensive research on the beneficial and potentially harmful effects of $\mathrm{CO}$ has been conducted, prior findings have remained inconsistent (Zhu \& Nakata, 2007). According to this research, the contradictory findings could be the result of a failure to account for confounding variables such as ME. Thus, by examining the effect of a contextual factor on the CO-SME performance relationship, this study contributes to the existing body of knowledge.

\section{Practical Implications}

Practically, this study has significant implications because it enables SME managers to focus their efforts on increasing their $\mathrm{CO}$, which is a more efficiency strategy given that SMEs commonly lack the resources ability to perform comprehensive marketing study, as recommended in the marketing domain (Kadic-Maglajlic, et al., 2017; Tajeddini, et al., 2013). This is because through focusing on customer satisfaction, small-oriented firms in Saudi Arabia can allocate their limited resources to providing more comprehensive services and thereby maximize their performance (Tang, T. W. (2014). As small and medium-sized enterprises are extremely important for generating customer orientation is imperative, on the other hand, it is also critical for managers and owners of these companies to know that there is always a compromise to be made between investment in $\mathrm{CO}$ and time (Homburg et al., 2011). Also, it is time- and money intensive to track down customer requirements all the way through the customer acquisition process (Brickman et al., 2012). The real value, however, doesn't just lie in the understanding of customers, but in the development of new products and services, which are resource intensive as well (Kadic-Maglajlic et al., 2017). As a result, given these moderating factors, improved the relationship between $\mathrm{CO}$ and firm performance is sometimes necessary (Pekovic \& Rolland, 2016; Neneh, 2018).

\section{Conclusion and Limitations}

This study looked at the relationship between $\mathrm{CO}$, marketing ethics, and organization performance in a KSA. The paper contributes to the growing body of literature that identifies $\mathrm{CO}$ as a distinct internal strategic orientation capable of interacting with other factors to improve business performance. This reaffirms the critical role of $\mathrm{CO}$, which has been largely implied by market orientation's multifaceted nature. Because SMEs are frequently resourceconstrained, they can direct their limited resources toward developing $\mathrm{CO}$ rather than establishing all market orientation tenets. With the business environment becoming more competitive as a result of globalization, SMEs must find ways of ensuring their long-term viability now more than ever. As a result, the potential benefits of customer orientation can be extremely beneficial for SMEs in Saudi Arabia, as they can leverage their proximity to customers to differentiate themselves from large businesses and capitalize on niche existing market opportunities by providing superior customer value. Furthermore, the study discovered that when marketing ethics were high versus low, the relationship between customer orientation and firm performance was less positive. This is completely counter-intuitive, as it contradicts resource theory, which has increasingly suggested that businesses should consider marketing ethics in order to improve their performance. The importance of SMEs developing practice 
Volume 3 Issue 8 (June 2021) PP. 119-138 DOI 10.35631/AIJBES.38008

ethics, particularly marketing ethics, which can significantly improve a business's competitiveness and performance, cannot be overstated.

As with previous studies, this one has some limitations that necessitate additional research. To begin, this study examined the moderating effect of ME on the relationships between $\mathrm{MO}$ and the performance of SMEs in the KSA context. Thus, future research can concentrate on examining additional variables that may affect this relationship. Second, the current study is focused on SMEs. Thus, future research can focus on MSMEs or large firms. Third, this study is being conducted in the Kingdom of Saudi Arabia. Thus, future studies can replicate the findings in different countries in order to generalize the findings.

\section{References}

Abdulrab, M., Alwaheeb, M. A., Al-Mamary, Y. H., Alshammari, N. G., Balhareth, H., Soltane, H. B., \& Saleem, I. (2020). Effect of entrepreneurial orientation and strategic orientations on financial and nonfinancial performance of small and medium enterprises in Saudi Arabia. Journal of Public Affairs, (In press), 1-11. https://doi.org/10.1002/pa.2305.

Abratt, R., Nel, D., \& Higgs, N. S. (1992). An examination of the ethical beliefs of managers using selected scenarios in a cross-cultural environment. Journal of business ethics, 11(1), 29-35. https://doi.org/10.1007/BF00871989.

Ahmad, S. Z. (2012). Micro, small and medium-sized enterprises development in the Kingdom of Saudi Arabia. World Journal of Entrepreneurship, Management and Sustainable Development, 8(4), 217-232. https://doi.org/10.1108/20425961211276606.

Akhavan, P., Ramezan, M., Moghaddam, J. Y., \& Mehralian, G. (2014). Exploring the relationship between ethics, knowledge creation and organizational performance: Case study of a knowledge-based organization. VINE: The journal of information and knowledge management systems, 44(1), 42-58. https://doi.org/10.1108/VINE-022013-0009.

Aldakhil, A. M., Aamir, A., Nassani, A. A., \& Askar, S. E. (2020). Exploring the Nexus Between the Market Orientation, Market Performance and Financial Performance of Manufacturing Firms in KSA: Does the Supply Chain Strategy Matter? Revista Argentina de Clínica Psicológica, 29(4), 652.

Al-Hakimi, M., \& Borade, D. B. (2020). The impact of entrepreneurial orientation on the supply chain resilience. Cogent Business and Management, 7(1), 1-18. https://doi.org/10.1080/23311975.2020.1847990.

Ali, G. A., Hilman, H., \& Gorondutse, A. H. (2020). Effect of entrepreneurial orientation, market orientation and total quality management on performance. Benchmarking: An International Journal. https://doi.org/10.1108/BIJ-08-2019-0391.

Al-Nashmi, M. M., \& Almamary, A. A. (2017). The relationship between Islamic marketing ethics and brand credibility. Journal of Islamic Marketing.

Alpkan, L., Yilmaz, C., \& Kaya, N. (2007). Market orientation and planning flexibility in SMEs: performance implications and an empirical investigation. International Small Business Journal, 25(2), 152-172. https://doi.org/10.1177/0266242607074518.

Alshurideh, M., Al Kurdi, B. H., Vij, A., Obiedat, Z., \& Naser, A. (2016). Marketing ethics and relationship marketing-An empirical study that measure the effect of ethics practices application on maintaining relationships with customers. International Business Research, 9(9), 78-90. 
Volume 3 Issue 8 (June 2021) PP. 119-138 DOI 10.35631/AIJBES.38008

Alteren, G., \& Tudoran, A. A. (2016). Enhancing export performance: Betting on customer orientation, behavioral commitment, and communication. International Business Review, 25(1), 370-381. https://doi.org/10.1016/j.ibusrev.2015.07.004.

Altuntaş, G., Semerciöz, F., \& Eregez, H. (2013). Linking strategic and market orientations to organizational performance: the role of innovation in private healthcare organizations. Procedia-Social and Behavioral Sciences, 99, 413-419.

Amin, M., Thurasamy, R., Aldakhil, A. M., \& Kaswuri, A. H. B. (2016). The effect of market orientation as a mediating variable in the relationship between entrepreneurial orientation and SMEs performance. Nankai Business Review International, 7(1), 3959. https://doi.org/10.1108/NBRI-08-2015-0019.

Anggadwita, G., \& Mustafid, Q. Y. (2014). Identification of factors influencing the performance of small medium enterprises (SMEs). Procedia-Social and Behavioral Sciences, 115, 415-423. https://doi.org/10.1016/j.sbspro.2014.02.448.

Appiah-Adu, K., \& Singh, S. (1998). Customer orientation and performance: a study of SMEs. Management decision, 36(6), 385-394. https://doi.org/10.1108/00251749810223592.

Asikhia, O. (2010). Customer orientation and firm performance among Nigerian small and medium scale businesses. International Journal of Marketing Studies, 2(1), 197-212. https://doi.org/10.5539/IJMS.V2N1P197.

Baker, W. E., \& Sinkula, J. M. (1999). The synergistic effect of market orientation and learning orientation on organizational performance. Journal of the academy of marketing science, 27(4), 411-427. https://doi.org/10.1177/0092070399274002.

Bamfo, B. A., \& Kraa, J. J. (2019). Market orientation and performance of small and medium enterprises in Ghana: The mediating role of innovation. Cogent Business \& Management, 6(1), 1-16. https://doi.org/10.1080/23311975.2019.1605703.

Bhuian, S. N. (1997). Exploring market orientation in banks: an empirical examination in Saudi Arabia. Journal of Services Marketing, 11(5), 317-328. https://doi.org/10.1108/08876049710176006.

Bhuian, S. N. (1998). An empirical examination of market orientation in Saudi Arabian manufacturing companies. Journal of business research, 43(1), 13-25. https://doi.org/10.1016/S0148-2963(97)00130-6.

Bhuian, S. N., \& Habib, M. (2005). The relationship between entrepreneurship, market orientation and performance: a test in Saudi Arabia. Journal of Transnational Management, 10(1), 79-98. https://doi.org/10.1300/J482v10n01_06.

Brik, A. B., Rettab, B., \& Mellahi, K. (2011). Market orientation, corporate social responsibility, and business performance. Journal of Business Ethics, 99(3), 307-324. https://doi.org/10.1007/s10551-010-0658-z.

Brockman, B. K., Jones, M. A., \& Becherer, R. C. (2012). Customer orientation and performance in small firms: Examining the moderating influence of risk-taking, innovativeness, and opportunity focus. Journal of Small Business Management, 50(3), 429-446. https://doi.org/10.1111/j.1540-627x.2012.00361.x.

Cheung, M. F., \& To, W. M. (2020). The Effect of Consumer Perceptions of the Ethics of Retailers on Purchase Behavior and Word-of-Mouth: The Moderating Role of Ethical Beliefs. Journal of Business Ethics, 1-18.

Chin, C. H., Lo, M. C., \& Ramayah, T. (2013). Market orientation and organizational performance: The moderating role of service quality. Sage Open, 3(4), 1-14. https://doi.org/10.1177/2158244013512664.

Chu, Z., Wang, Q., \& Lado, A. A. (2016). Customer orientation, relationship quality, and performance. The international journal of logistics management, 27(3), 738-754. https://doi.org/10.1108/IJLM-08-2013-0093. 
Volume 3 Issue 8 (June 2021) PP. 119-138 DOI 10.35631/AIJBES.38008

Cicea, C., Popa, I., Marinescu, C., \& Cătălina Ștefan, S. (2019). Determinants of SMEs' performance: evidence from European countries. Economic research, 32(1), 16021620. https://www.tandfonline.com/loi/rero20.

Danso, A., Poku, K., \& Agyapong, A. (2017). Mediating role of internal communications in market orientation and performance of mobile telecom firms: Evidence from Ghana. Cogent Business \& Management, 4(1), 1-15. https://doi.org/10.1080/23311975.2017.1403713.

Diamantopoulos, A., \& Hart, S. (1993). Linking market orientation and company performance: preliminary evidence on Kohli and Jaworski's framework. Journal of strategic marketing, 1(2), 93-121. https://doi.org/10.1080/09652549300000007.

Dubinsky, A. J., \& Ingram, T. N. (1984). Correlates of salespeople's ethical conflict: An exploratory investigation. Journal of Business Ethics, 3(4), 343-353. https://doi.org/10.1007/BF00381759.

Feng, T., Wang, D., Lawton, A., \& Luo, B. N. (2019). Customer orientation and firm performance: The joint moderating effects of ethical leadership and competitive intensity. Journal of Business Research, 100, 111-121. https://doi.org/10.1016/j.jbusres.2019.03.021.

Ferrell, O. C. (2007). Nature and scope of marketing ethics. In G. T. Gundlach, L. Block \& W. Wilkie (Eds.), Explorations of marketing in society (pp. 858-875). Mason, $\mathrm{OH}$ : Thomson Higher Education.

Ferrell, O. C., \& Ferrell, L. (2021). New directions for marketing ethics and social responsibility research. Journal of Marketing Theory and Practice, 29(1), 13-22.

Frambach, R. T., Fiss, P. C., \& Ingenbleek, P. T. (2016). How important is customer orientation for firm performance? A fuzzy set analysis of orientations, strategies, and environments. Journal of Business Research, 69(4), 1428-1436. https://doi.org/10.1016/j.jbusres.2015.10.120.

Gaur, S. S., Vasudevan, H., \& Gaur, A. S. (2011). Market orientation and manufacturing performance of Indian SMEs: Moderating role of firm resources and environmental factors. European Journal of Marketing, 45(7/8), 1172-1193. https://doi.org/10.1108/03090561111137660.

Genc, E., Dayan, M., \& Genc, O. F. (2019). The impact of SME internationalization on innovation: The mediating role of market and entrepreneurial orientation. Industrial $\begin{array}{lll}\text { Marketing } & \text { Management, 253-264. }\end{array}$ https://doi.org/10.1016/j.indmarman.2019.01.008.

Gopang, M. A., Nebhwani, M., Khatri, A., \& Marri, H. B. (2017). An assessment of occupational health and safety measures and performance of SMEs: An empirical investigation. Safety science, 93, 127-133. https://doi.org/10.1016/j.ssci.2016.11.024.

Gotteland, D., \& Boulé, J. M. (2006). The market orientation-new product performance relationship: Redefining the moderating role of environmental conditions. International Journal of Research in Marketing, 23(2), 171-185. https://doi.org/10.1016/j.ijresmar.2005.08.001.

Grawe, S. J., Chen, H., \& Daugherty, P. J. (2009). The relationship between strategic orientation, service innovation, and performance. International Journal of Physical Distribution \& Logistics Management, 39(4), 282-300. https://doi.org/10.1108/09600030910962249.

Greenley, G. E. (1995). Market orientation and company performance: empirical evidence from UK companies. British journal of management, 6(1), 1-13. https://doi.org/10.1111/j.1467-8551.1995.tb00082.x. 
Volume 3 Issue 8 (June 2021) PP. 119-138 DOI 10.35631/AIJBES.38008

Grissemann, U., Plank, A., \& Brunner-Sperdin, A., (2013). Enhancing business performance of hotels: The role of innovation and customer orientation. International Journal of Hospitality Management, 33, 347-356. http://dx.doi.org/10.1016/j.ijhm.2012.10.005.

Gupta, V. K., \& Batra, S. (2016). Entrepreneurial orientation and firm performance in Indian SMEs: Universal and contingency perspectives. International Small Business Journal, 34(5), 660-682. https://doi.org/10.1177/0266242615577708.

Hai, H., Xuan, N., Thao, T., \& Hien, P. (2021). The effects of strategy and market orientation on the performance of Vietnamese startups. Management Science Letters, 11(4), 13571366. https://doi.org/10.5267/j.msl.2020.11.004.

Harris, L. C. (2001). Market Orientation and Performance: Objective and Subjective Empirical Evidence from UK Companies. Journal of Management Studies, 38(1), 17-43. https://doi.org/10.1111/1467-6486.00226.

Hassen, Y., \& Singh, A. (2020). The Effect of Market Orientation on the Performance of Small and Medium Enterprises in Case of Amhara Region, Ethiopia. Journal of New Business Ventures, 1(1-2), 92-109. https://doi.org/10.1177/2632962X20961051.

He, H., \& Harris, L. (2020). The Impact of Covid-19 Pandemic on Corporate Social Responsibility and Marketing Philosophy. Journal of Business Research, 116(1), 176182. https://doi.org/10.1016/j.jbusres.2020.05.030.

Hilman, H., \& Kaliappen, N. (2014). Market orientation practices and effects on organizational performance: Empirical insight from Malaysian hotel industry. Sage Open, 4(4), 1-8. https://doi.org/10.1177/2158244014553590.

Hilman, H., Ali, G. A., \& Gorondutse, A. H. (2019). The relationship between TQM and SMEs' performance. International Journal of Productivity and Performance Management, 69(1), 61-84. https://doi.org/10.1108/IJPPM-02-2019-0059.

Homburg, C., \& Pflesser, C. (2000). A multiple-layer model of market-oriented organizational culture: Measurement issues and performance outcomes. Journal of marketing research, 37(4), 449-462. https://doi.org/10.1509/jmkr.37.4.449.18786.

Homburg, C., Müller, M., \& Klarmann, M. (2011). When should the customer really be king? On the optimum level of salesperson customer orientation in sales encounters. Journal of marketing, 75(2), 55-74. https://doi.org/10.1509/jm.75.2.55.

Hopkins, C. D., Ferrell, O. C., Ferrell, L., \& Hopkins, K. H. (2021). Changing Perceptions of Marketing Ethics and Social Responsibility in Principles of Marketing. Journal of Marketing Education, 0273475321995553.

Hosmer, L. T. (1994). Strategic planning as if ethics mattered. Strategic management journal, 15(S2), 17-34. https://doi.org/10.1002/smj.4250151003.

Howe, V., Hoffman, K. D., \& Hardigree, D. W. (1994). The relationship between ethical and customer-oriented service provider behaviors. Journal of Business Ethics, 13(7), 497506. https://doi.org/10.1007/BF00881295.

Hwang, Y. I., \& Chung, S. (2018). Market orientation, social responsibility, and performance in Korea's healthcare industry. International Journal of Healthcare Management, 11(4), 325-332. https://doi.org/10.1080/20479700.2017.1404728.

Jaworski, B. J., \& Kohli, A. K. (1993). Market orientation: antecedents and consequences. Journal of marketing, 57(3), 53-70. https://doi.org/10.1177/002224299305700304.

Jeddah Chamber of Commerce and Industry (2015). Small medium enterprises in Saudi Arabia report. Retrieved October 10, 2020 from: www.jcci.org.sa/English/Pages/default.aspx.

JEDDAH-CHAMBER. (2018). SMALL-MEDIUM ENTERPRISES IN SAUDI ARABIA REPORT. Retrieved from JEDDAH, Saudi Arabia: www.jcci.org.sa and WWW.JEG.ORG. 
Volume 3 Issue 8 (June 2021) PP. 119-138 DOI 10.35631/AIJBES.38008

Kadic-Maglajlic, S., Micevski, M., Arslanagic-Kalajdzic, M., \& Lee, N. (2017). Customer and selling orientations of retail salespeople and the sales manager's ability-to-perceiveemotions: A multi-level approach. Journal of Business Research, 80, 53-62. https://doi.org/10.1016/j.jbusres.2017.06.023.

Kingdom of Saudi Arabia (2016). Vision 2030 report. Retrieved October 10, 2020 from: http://vision2030.gov.sa/en/reports.

Kirca, A. H., Jayachandran, S., \& Bearden, W. O. (2005). Market orientation: A meta-analytic review and assessment of its antecedents and impact on performance. Journal of marketing, 69(2), 24-41. https://doi.org/10.1509/jmkg.69.2.24.60761.

Kohli, A. K., \& Jaworski, B. J. (1990). Market orientation: the construct, research propositions, and managerial implications. Journal of marketing, 54(2), 1-18.

Kraus, S., Rigtering, J. C., Hughes, M., \& Hosman, V. (2012). Entrepreneurial orientation and the business performance of SMEs: a quantitative study from the Netherlands. Review of Managerial Science, 6(2), 161-182.

KSA, General Authority of Statistics (2019). Retrieved November 8, 2018, from http://www.cdsi.gov.sa/en/node.

Kumar, V., Jones, E., Venkatesan, R., \& Leone, R. P. (2011). Is market orientation a source of sustainable competitive advantage or simply the cost of competing?. Journal of marketing, 75(1), 16-30. https://doi.org/10.1509/jm.75.1.16.

Lagace, R. R., Dahlstrom, R., \& Gassenheimer, J. B. (1991). The relevance of ethical salesperson behavior on relationship quality: the pharmaceutical industry. Journal of Personal Selling \& Sales Management, 11(4), 39-47.

Li, Y., Zhao, Y., Tan, J., \& Liu, Y. (2008). Moderating effects of entrepreneurial orientation on market orientation-performance linkage: Evidence from Chinese small firms. Journal of small business management, 46(1), 113-133.

Long, B. S., \& Driscoll, C. (2008). Codes of ethics and the pursuit of organizational legitimacy: Theoretical and empirical contributions. Journal of Business Ethics, 77(2), 173-189. https://doi.org/10.1007/s10551-006-9307-y.

Luo, X., \& Bhattacharya, C. B. (2006). Corporate social responsibility, customer satisfaction, and market value. Journal of marketing, 70(4), 1-18. https://doi.org/10.1509/jmkg.70.4.001.

Luo, X., Hsu, M. K., \& Liu, S. S. (2008). The moderating role of institutional networking in the customer orientation-trust/commitment-performance causal chain in China. Journal of the Academy of Marketing Science, 36(2), 202-214. https://doi.org/10.1007/s11747-007-0047-z.

Mahmoud, M. A., \& Hinson, R. E. (2012). Market orientation, innovation and corporate social responsibility practices in Ghana's telecommunication sector. Social Responsibility Journal, 8(3), 327-346. https://doi.org/10.1108/17471111211247910.

Mahmoud, M. A., Blankson, C., Owusu-Frimpong, N., Nwankwo, S., \& Trang, T. P. (2016). Market orientation, learning orientation and business performance: the mediating role of innovation. International Journal of Bank Marketing, 34(5), 623-648.

Mahmoud, M. A., Kastner, A., \& Yeboah, J. (2010). Antecedents, environmental moderators and consequences of market orientation: A study of pharmaceutical firms in Ghana. Journal of Medical Marketing, 10(3), 231-244. https://doi.org/10.1057/jmm.2010.12.

Majtán, Š., \& Dubcová, G. (2008). The Ethics in the Product Marketing. Ekonomika a Management, (2), 1-10.

Masa'deh, R., Al-Henzab, J., Tarhini, A., \& Obeidat, B. Y. (2018). The associations among market orientation, technology orientation, entrepreneurial orientation and 
Volume 3 Issue 8 (June 2021) PP. 119-138 DOI 10.35631/AIJBES.38008

organizational performance. Benchmarking: An International Journal, 25(8), 31173142. https://doi.org/10.1108/BIJ-02-2017-0024.

Maurya, U. K., Mishra, P., Anand, S., \& Kumar, N. (2015). Corporate identity, customer orientation and performance of SMEs: Exploring the linkages. IIMB Management Review, 27(3), 159-174. https://doi.org/10.1016/j.iimb.2015.05.001.

Ministry of Commerce and Industry (2018). Industry in the Kingdom renaissance continues. www.mci.gov.sa.

Ministry of Commerce and Investment (2019). Small and Medium Industries. Retrieved January 15, 2020, from https://mci.gov.sa/Pages/default.aspx.

Ministry of Economy and Planning (2018). The achievements of the development plans " Facts and Figures " Retrieved May 11, 2020, from http://www.mep.gov.sa.

Mostafiz, M. I., Sambasivan, M., \& Goh, S. K. (2021). Antecedents and consequences of market orientation in international B2B market: role of export assistance as a moderator. Journal of Business \& Industrial Marketing, (In press), 1-50. https://doi.org/10.1108/JBIM-09-2019-0411.

Murphy, P. E. (2002). Marketing ethics at the millennium: Review, reflections, and recommendations. The Blackwell guide to business ethics, 165-185. https://doi.org/10.1002/9781405164771.ch8.

Najafi-Tavani, S., Sharifi, H., \& Najafi-Tavani, Z. (2016). Market orientation, marketing capability, and new product performance: The moderating role of absorptive capacity. Journal of Business Research, 69(11), 5059-5064. https://doi.org/10.1016/j.jbusres.2016.04.080.

Narver, J. C., \& Slater, S. F. (1990). The effect of a market orientation on business profitability. Journal of marketing, 54(4), 20-35. https://doi.org/10.1177/002224299005400403.

Neneh, B. N. (2016). Market orientation and performance: the contingency role of external environment. Environmental economics, $7(2), \quad 130-137$. https://doi.org/10.21511/ee.07(2).2016.14.

Neneh, B. N. (2018). Customer orientation and SME performance: the role of networking ties. African Journal of Economic and Management Studies, 9(2), 178-196. https://doi.org/10.1108/AJEMS-03-2017-0043.

Newman, A., Prajogo, D., \& Atherton, A. (2016). The influence of market orientation on innovation strategies. Journal of service theory and practice, 26(1), 72-90.

O’Dwyer, M., \& Gilmore, A. (2019). Competitor orientation in successful SMEs: An exploration of the impact on innovation. Journal of Strategic Marketing, 27(1), 21-37. https://doi.org/10.1080/0965254X.2017.1384040.

Oakes, G. (1990). The sales process and the paradoxes of trust. Journal of Business Ethics, 9(8), 671-679. https://doi.org/10.1007/BF00383394.

Oduro, S., \& Haylemariam, L. G. (2019). Market orientation, CSR and financial and marketing performance in manufacturing firms in Ghana and Ethiopia. Sustainability Accounting, Management and Policy Journal, 10(3), 398-426. https://doi.org/10.1108/SAMPJ-112018-0309.

Orlitzky, M., Schmidt, F. L., \& Rynes, S. L. (2003). Corporate social and financial performance: A meta-analysis. Organization studies, 24(3), 403-441. https://doi.org/10.1177/0170840603024003910.

Pekovic, S., \& Rolland, S. (2016). Customer orientation and firm's business performance. European Journal of Marketing, 50(12), 2162-2191. https://doi.org/10.1108/EJM-082015-0584. 
Volume 3 Issue 8 (June 2021) PP. 119-138 DOI 10.35631/AIJBES.38008

Pelham, A. M. (1997). Market orientation and performance: the moderating effects of product and customer differentiation. Journal of Business \& Industrial Marketing, 12(5), 276296. https://doi.org/10.1108/08858629710183257.

Pinho, J. C. (2008). TQM and performance in small medium enterprises: The mediating effect of customer orientation and innovation. International journal of quality \& reliability management, 25(3), 256-275. https://doi.org/10.1108/02656710810854278.

Pongwiritthon, R., \& Awirothananon, T. (2014). Customer orientation and firm performance among Thai SMEs. International Journal of Applied Business and Economic Research, 12(3), 867-883.

PWC (2019). Middle East Family Business Survey. Retrieved 2021, from https://www.pwc.com/m1/en/publications/documents/family-business-survey2019.pdf.

Qu, R. (2009). The impact of market orientation and corporate social responsibility on firm performance. Asia Pacific Journal of Marketing and Logistics, 21(4), 570-582. https://doi.org/10.1108/13555850910997607.

Reijonen, H., Laukkanen, T., Komppula, R., \& Tuominen, S. (2012). Are growing SMEs more market-oriented and brand-oriented?. Journal of Small Business Management, 50(4), 699-716. https://doi.org/10.1111/j.1540-627X.2012.00372.x.

Roberts, P. W., \& Dowling, G. R. (2002). Corporate reputation and sustained superior financial performance. Strategic management journal, 23(12), 1077-1093. https://doi.org/10.1002/smj.274.

Saha, R., Cerchione, R., Singh, R., \& Dahiya, R. (2020). Effect of ethical leadership and corporate social responsibility on firm performance: A systematic review. Corporate Social Responsibility and Environmental Management, 27(2), 409-429.

Šályová, S., Táborecká-Petrovičová, J., Nedelová, G., \& Ďad’o, J. (2015). Effect of marketing orientation on business performance: A study from Slovak foodstuff industry. Procedia Economics and Finance, 34, 622-629. https://doi.org/10.1016/S2212-5671(15)016779.

Sheehan, M. (2014). Human resource management and performance: Evidence from small and medium-sized firms. International Small Business Journal, 32(5), 545-570. https://doi.org/10.1177/0266242612465454.

Slater, S. F., \& Narver, J. C. (1994). Does competitive environment moderate the market orientation-performance relationship?. Journal of marketing, 58(1), 46-55. https://doi.org/10.1177/002224299405800104.

Smirnova, M. M., Rebiazina, V. A., \& Frösén, J. (2018). Customer orientation as a multidimensional construct: Evidence from the Russian markets. Journal of Business Research, 86, 457-467.. https://doi.org/10.1016/j.indmarman.2010.09.009.

Smirnova, M., Naudé, P., Henneberg, S. C., Mouzas, S., \& Kouchtch, S. P. (2011). The impact of market orientation on the development of relational capabilities and performance outcomes: The case of Russian industrial firms. Industrial Marketing Management, 40(1), 44-53. https://doi.org/10.1016/j.indmarman.2010.09.009

Solberg, C. A., \& Olsson, U. H. (2010). Management orientation and export performance: the case of Norwegian ICT companies. Baltic Journal of Management, 5(1), 28-50. https://doi.org/10.1108/17465261011016540.

Sørensen, H. E. (2009). Why competitors matter for market orientation. European journal of marketing, 43(5/6), 735-761. https://doi.org/10.1108/03090560910947025.

Sørensen, H. E. (2011). Resource specialization, customer orientation, and firm performance: an empirical investigation of valuable resources. Journal of Strategic Marketing, 19(4), 395-412. https://doi.org/10.1080/0965254X.2011.586718. 
Volume 3 Issue 8 (June 2021) PP. 119-138 DOI 10.35631/AIJBES.38008

Tajeddini, K., \& Ratten, V. (2020). The moderating effect of brand orientation on inter-firm market orientation and performance. Journal of Strategic Marketing, 28(3), 194-224. https://doi.org/10.1080/0965254X.2017.1293138.

Tajeddini, K., Elg, U., \& Trueman, M. (2013). Efficiency and effectiveness of small retailers: The role of customer and entrepreneurial orientation. Journal of Retailing and Consumer Services, 20(5), 453-462. https://doi.org/10.1016/j.jretconser.2013.05.004.

Takala, T., \& Uusitalo, O. (1996). An alternative view of relationship marketing: a framework for ethical analysis. European Journal of marketing, 30(2), 45-60. https://doi.org/10.1108/03090569610106644.

Tang, T. W. (2014). Becoming an ambidextrous hotel: The role of customer orientation. International Journal of Hospitality Management, 39, 1-10. https://doi.org/10.1016/j.ijhm.2014.01.008.

Thoumrungroje, A., \& Racela, O. (2013). The contingent role of customer orientation and entrepreneurial orientation on product innovation and performance. Journal of Strategic Marketing, 21(2), 140-159. http://dx.doi.org/10.1080/0965254X.2012.742129.

Udriyah, U., Tham, J., \& Azam, S. (2019). The effects of market orientation and innovation on competitive advantage and business performance of textile SMEs. Management Science Letters, 9(9), 1419-1428.

Vitell, S. J., Nwachukwu, S. L., \& Barnes, J. H. (1993). The effects of culture on ethical decision-making: An application of Hofstede's typology. Journal of business Ethics, 12(10), 753-760.

Vitell, S. J., Rallapalli, K. C., \& Singhapakdi, A. (1993). Marketing norms: The influence of personal moral philosophies and organizational ethical culture. Journal of the Academy of Marketing Science, 21(4), 331-337.

Waddock, S. A., \& Graves, S. B. (1997). The corporate social performance-financial performance link. Strategic management journal, 18(4), 303-319. https://doi.org/10.1002/(SICI)1097-0266(199704)18:4<303::AID-SMJ869>3.0.CO;2G.

Wang, Q., Zhao, X., \& Voss, C. (2016). Customer orientation and innovation: A comparative study of manufacturing and service firms. International Journal of Production Economics, 171, 221-230. https://doi.org/10.1016/j.ijpe.2015.08.029.

Williams, O. F., \& Murphy, P. E. (1990). The ethics of virtue: A moral theory for marketing. $\begin{array}{llll}\text { Journal of } & \text { Macromarketing, } & 10(1),\end{array}$ https://doi.org/10.1177/027614679001000103.

Yoo, B., \& Donthu, N. (2002). The effects of marketing education and individual cultural values on marketing ethics of students. Journal of Marketing Education, 24(2), 92-103.

Yustian, O. (2021). Uncertainty of the business environment affecting business success due to the Covid-19 pandemic. Management Science Letters, 11(5), 1549-1556. https://doi.org/10.5267/j.msl.2020.12.018.

Zhou, K. Z., Brown, J. R., Dev, C. S., \& Agarwal, S. (2007). The effects of customer and competitor orientations on performance in global markets: a contingency analysis. Journal of International Business Studies, 38(2), 303-319. https://doi.org/10.1057/palgrave.jibs.8400259.

Zhu, Z., \& Nakata, C. (2007). Reexamining the link between customer orientation and business performance: The role of information systems. Journal of marketing theory and practice, 15(3), 187-203. https://doi.org/10.2753/MTP1069-6679150301. 